\title{
Starch supplementation modulates amylase enzymatic properties and amylase B mRNA level in the digestive gland of the Pacific oyster Crassostrea gigas
}

\author{
A. Huvet ${ }^{a}{ }^{a}$, F. Jeffroy ${ }^{a}$, J.Y. Daniel ${ }^{a}$, C. Quéré ${ }^{a}$, P. Le Souchu ${ }^{a}$, A. Van Wormhoudt ${ }^{b}$, P. Boudry ${ }^{a}$, \\ J. Moal ${ }^{\mathrm{a}}$, J.F. Samain ${ }^{\mathrm{a}}$ \\ a IFREMER, UMR CNRS 6539, Laboratoire des Sciences de l'Environnement Marin, BP 70, 29280 Plouzané, \\ France \\ ${ }^{\text {b }}$ Station de Biologie Marine du Muséum National d'Histoire Naturelle, BP225, 29900 Concarneau, France \\ *: Corresponding author: A. Huvet, Tel.: + 332982246 93; fax: + 3329822 46 53, email address : \\ ahuvet@ifremer.fr \\ fannyjeffroy@yahoo.fr, Jean.Yves.Daniel@ifremer.fr, Claudie.Quere@ifremer.fr, Pierrick.Le.Souchu@ifremer.fr, \\ avw@mnhn.fr, pboudry@ifremer.fr, imoal@ifremer.fr, ifsamain@gmail.com
}

\begin{abstract}
:
In the oyster Crassostrea gigas consumption-related traits, amylase properties and growth were found to be linked through genotypes that differed for polymorphism in the two amylase genes $A M Y A$ and $A M Y B$. Modulation of $A M Y A$ mRNA level had already been observed in response to food availability, whereas the functional role of $A M Y B$ was still unknown. To improve knowledge about the regulation of amylase expression in $C$. gigas and the respective roles of the two genes, we made an assay of amylase expression at mRNA and enzymatic levels in the digestive gland of oysters that had received dietary supplements of starch. After 18 days, a significant increase of translatable mRNA for AMYB was observed, with a correlated increase in Michaelis-Menten constant $K m$ values and a decrease in total amylase activity. This modulation is the first evidence of observable functioning of $A M Y B$ in digestive processes. Amylase $B$ is suggested to display a higher $K m$ than amylase $A$, offering a means of adapting to high substrate concentrations. The highest starch supplement level $\left(10 \mathrm{mg} \mathrm{L}^{-1}\right)$ induced alteration in oyster physiology. The $1 \mathrm{mg} \mathrm{L}^{-1}$ treatment should be tested as a practical food supplement that could lead to growth benefits for oysters.
\end{abstract}

Keywords: a-amylase; Crassostrea gigas; digestive enzyme; Michaelis-Menten constant; regulation 
Knowledge of feeding strategies and adaptive digestive capacities of bivalves under different food conditions and their effects on phenotypic traits, such as growth, is of major interest for aquaculture. Digestive enzyme activities and the mechanisms controlling them may, therefore, be important in maximizing absorption efficiencies and food conversion efficiencies. Indeed, activities of digestive enzymes have been reported to affect absorption efficiency for their corresponding substrates (Bayne, 1976; Samain et al., 1991, Ibarrola et al., 1998, 2000), and this appears to be one of the principal factors explaining in situ growth variability of the Pacific oyster Crassostrea gigas (Huvet et al., 2003). Among digestive enzymes, $\alpha$-amylase ( $\alpha-1,4$ glucan-4-glucanohydrolase) is a key enzyme for carbohydrate digestion and is possibly a limiting factor in oyster absorption efficiency (Moal et al., 2000; Sellos et al., 2003). More broadly, $\alpha$-amylase can represent individual energy status, as observed in Drosophila when starch is the only carbohydrate source in the substrate (Powell and Andjelkovic, 1983). $\alpha$-amylase catalyses the hydrolysis of internal $(\alpha-1,4)$ glucoside bonds in starch of related poly and oligosaccharides. In C. gigas, two genes (AMYA and $A M Y B$ ) have been characterized that code for two amylase mRNAs (Sellos et al., 2003). The polymorphism of these two genes was analysed, revealing associations with growth, consumption related traits and amylase expression (Prudence et al., 2006; Huvet et al., 2008).

Numerous articles emphasize the potential effects of external factors on the regulation processes of digestive enzymes such as amylase. In rat, for example, amylase activity was reported to vary at cellular and molecular levels in response to the carbohydrate content of the diet (Wicker et al., 1984). Amylase isozymes were also reported to vary in Gammarus and to be induced by a diet rich in glycogen (Borowsky, 1984; Guarna and Borowsky, 1995). Adaptation of amylase enzyme was also observed in the shrimp Penaus vannamei, depending on casein and protein sources in the diet (Le Moullac et al., 1997), and in Artemia salina according to particulate starch concentration in diet (Samain et al., 1980). In the disk abalone Haliotis discus discus, mRNA expression of the $\alpha$-amylase gene appeared to be negatively affected by starvation and positively affected by food availability (Nikapitiya et al., 2009). In C. gigas, we have demonstrated that food availability (i.e., different quantities of the same food) constitutes an external regulatory factor for amylase expression. We observed that $A M Y A$ could be regulated at the mRNA level when food varied quantitatively, whereas $A M Y B$ was either not regulated under these conditions or present at such weak mRNA levels that its functional role was questionable (Huvet et al., 2003; Huvet et al., 2008). Diet quality was also shown to have an effect on digestive processes in oysters, mainly because classes of algal species vary in carbohydrate and starch contents (Moal et al., 1987). Therefore, investigating effects of diet quality on amylase properties is valuable for understanding adaptive digestive capacities of bivalves and the functioning of amylase genes A and B.

To improve knowledge about the regulation of amylase expression, the respective roles of amylase genes $A$ and $B$, and the relationships between enzymatic properties and absorption processes in oyster, we made an assay of amylase expression at mRNA and enzymatic levels, in the digestive gland of oysters provided with dietary supplements of starch, the substrate of amylase. Our results suggest that the $\alpha$-amylase B gene could play a role in the adaptation to starch variation in the diet. 


\subsection{Biological material}

Oysters were produced at the Ifremer hatchery in La Tremblade (Charente Maritime, France) by a controlled spawning with 30 wild oysters collected in Marennes-Oléron Bay. Juveniles were then reared at the Ifremer nursery in Bouin (Vendée, France). Three-year-old oysters (mean total weight $=98 \pm 6 \mathrm{~g}$ ) were then transferred to the Ifremer shellfish facilities in Argenton (Brittany, France), where they underwent an acclimation period of 8 days at $17.0 \pm 1.0^{\circ} \mathrm{C}$ in seawater filtered at $20 \mu \mathrm{m}$ without food supply, before experimental treatments were started.

\subsection{Experimental design}

Oysters $(n=160)$ were conditioned in duplicate raceways of $5 \mu$ m-filtered seawater $(106 \mathrm{~L} / \mathrm{h})$ at $17.0 \pm 1.0{ }^{\circ} \mathrm{C}$ and fed a diet of Chaetoceros gracilis at a daily ration equal to $8 \%$ dry weight algae/dry weight oyster for the control (c), plus 3 other treatments with different final starch supplement concentrations $1 \mathrm{mg} \mathrm{L}^{-1}, 5 \mathrm{mg} \mathrm{L}^{-1}$ and $10 \mathrm{mg} \mathrm{L}^{-1}$. Native wheat starch (Avebe, The Netherlands) was dissolved in $5 \mu \mathrm{m}$-filtered seawater to obtain a nominal starch solution. This solution was distributed to duplicated raceways using a peristaltic pump along a $24 \mathrm{~h}$ cycle to ensure the required final concentration. Additionally, a pump was used in each raceway to avoid starch sedimentation. To validate the procedure, the concentrations of starch were followed during 24 hours in raceways without animals. Quantity and size of wheat starch particles $(20 \mu \mathrm{m})$ were estimated in the water column using a coulter counter and remained stable at $0,3,9$ and $24 \mathrm{~h}$ assessing the solubility of starch in seawater and the particulate matter holding in the raceway during $24 \mathrm{~h}$ (without significant degradation of the starch particles).

After 10 (T1) and 18 (T2) days of conditioning, 16 oysters were randomly collected per raceway (i.e. 32 oysters per treatment). Collected oysters were weighed (wet flesh weight) and their digestive glands immediately dissected, pooled (4 pools of 8 glands resulting in 2 pools per raceway), frozen in liquid nitrogen, crushed to a fine powder at $-196{ }^{\circ} \mathrm{C}$ with a Dangoumau mill and stored in liquid nitrogen until the RNA extraction and enzymatic assay were performed.

\subsection{Nucleic acid extractions and Reverse transcription - Polymerase Chain Reaction (RT-PCR) assay}

Total RNA was isolated using Extract-all reagent (Eurobio) at a concentration of $1 \mathrm{ml} / 50 \mathrm{mg}$

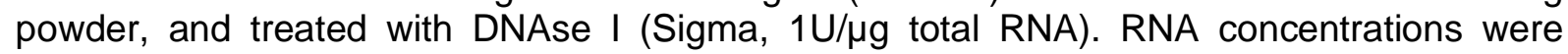
measured at $260 \mathrm{~nm}(1 \mathrm{OD}=40 \mathrm{\mu g} / \mathrm{ml}$ RNA) using an ND-1000 spectrophotometer (Nanodrop Technologies). RNA integrity was assessed using the Agilent 2100 Bioanalyzer (Agilent Technologies, Waldbronn, Germany). One $\mu \mathrm{g}$ of total RNA was reverse-transcribed following the protocol in Huvet et al. (2003) and amplified in triplicate by real time PCR according to Huvet et al. (2004), using specific primers (Huvet et al., 2008). The calculation of relative mRNA levels was normalized to Elongation Factor I (primers in Fabioux et al. 2004) as no significant differences in Ct values were observed for EFI between treatments $(P=0.104, \mathrm{CV}=2.5 \%)$. For a studied gene "i", results were expressed in arbitrary unit as 2 $\Delta \Delta \mathrm{Ct}$ (Pfaffl, 2001) with $\Delta \mathrm{Cq}=\mathrm{Cq}(\mathrm{i})-\mathrm{Cq}(E F I)$ and $\Delta \Delta \mathrm{Cq}=\Delta \mathrm{Cq}$ of cDNA sample $-\Delta \mathrm{Cq}$ of the cDNA reference. 


\subsection{Enzymatic analysis}

Amylase activity and apparent Michaelis-Menten constant $\left(K_{\mathrm{M}}\right)$ were evaluated on the replicate pools, using a Technicon autoanalyser according to Samain et al. (1977). Briefly, all these samples were ground in distilled water with $0.02 \mathrm{M} \mathrm{CaCl}_{2}$ before analysis. Amylase activity was then assayed at a substrate concentration of $1 \mathrm{mg} / \mathrm{ml}$ by determining starch hydrolysis according to the iodine reaction adapted to bivalve amylases. One unit of alphaamylase was defined as the amount of enzyme that degrades $1 \mathrm{mg} / \mathrm{min}$ starch at $45^{\circ} \mathrm{C}$. Soluble proteins were determined according to the method of Lowry et al. (1951). $K_{M}$ was determined from a serial dilution analysis of 0.07 to $1 \mathrm{mg} / \mathrm{min}$ starch.

\subsection{Data analysis}

Three-way split-split plot ANOVAs (adapted from Pernet et al., 2007) were conducted using STATGRAPHICS software. The unit of replication was the raceway in which the diet was applied ( $\mathrm{N}=2$ for each diet, except for mean flesh weight $\mathrm{N}=16$ ). The main plots were diet levels (control, 1,5 and $10 \mathrm{mg} \mathrm{L}^{-1}$ starch), subplots were replicated raceways, and subsubplots were sampling dates (10 and 18 days). Where differences were detected, multiple comparison tests were conducted with the Tukey's HSD method. Normality of the dataset was tested using Shapiro-Wilk. When necessary, data were log-transformed or square root transformed to achieve homogeneity of variances. Results are expressed as means \pm standard deviation. Statistical significances were reported at $\mathrm{P}<0.05$.

\section{Results}

The mean flesh weight of the oysters sampled after 18 days was $21.5 \%$ lower in the treatment with the highest starch $\left(10 \mathrm{mg} \mathrm{L}^{-1} \mathrm{starch}\right.$; mean flesh weight $=10.5 \pm 2.9 \mathrm{~g}$; Tables 1 and 2) than in the three other treatments, for which the mean flesh weight of the oysters appeared statistically similar (mean value $=13.4 \pm 4.1 \mathrm{~g}$ ).

For specific amylase activity, similar significant differences were observed between treatments, after 10 and 18 days, giving 3 distinct statistical groups (Table 2, Figure 1). Values decreased significantly from $2.27 \pm 0.08 \mathrm{Ul} / \mathrm{mg}$ protein in the control treatment to 1.41 $\pm 0.09 \mathrm{Ul} / \mathrm{mg}$ protein in the $1 \mathrm{mg} \mathrm{L}^{-1}$ treatment to $0.52 \pm 0.04 \mathrm{Ul} / \mathrm{mg}$ protein in the 5 and 10 $\mathrm{mg} \mathrm{L}^{-1}$ treatments. In contrast, the Michaelis-Menten constant $\left(K_{\mathrm{M}}\right)$ was higher in the starch treatments than in the control at 10 days (Table 2). The control showed the lowest $K_{\mathrm{M}}$ value $\left(0.37 \pm 0.01\right.$; Figure 2), 1 and $10 \mathrm{mg} \mathrm{L}^{-1}(0.53 \pm 0.01$ and $0.50 \pm 0.03 \mathrm{mg} / \mathrm{mL}$, respectively) were intermediate, to the highest value, $0.75 \pm 0.06 \mathrm{mg} / \mathrm{mL}$, was found in the $5 \mathrm{mg} \mathrm{L}^{-1}$ starch treatment. At 18 days, $K_{\mathrm{M}}$ values were very similar to those obtained at 10 days: $K_{\mathrm{M}}$ of the control and $1 \mathrm{mg} \mathrm{L}^{-1}$ treatment were the lowest and similar, whereas they were significantly different at $\mathrm{T} 1$, followed by the $10 \mathrm{mg} \mathrm{L}^{-1}$ and lastly the $5 \mathrm{mg} \mathrm{L}^{-1}$, which was the highest.

Analysis of amylase gene expression based on real time RT-PCR showed that, relative to elongation factor gene expression, only $A M Y B$ displayed significantly different levels depending on the conditions, increasing with substrate concentration (Table 2). Indeed, relative $A M Y B$ mRNA levels, showed two significantly different groups (Figure 3B). At 10 days, transcript level for the $10 \mathrm{mg} \mathrm{L}^{-1}$ treatment $(1.96 \pm 0.29 \mathrm{UI})$ was twice that of the control and $1 \mathrm{mg} \mathrm{L}^{-1}$ treatment (mean relative expression $=0.90 \pm 0.27 \mathrm{UI}$ ), the $5 \mathrm{mg} \mathrm{L}^{-1}$ treatment being intermediate (and not significantly different from $10 \mathrm{mg} \mathrm{L}^{-1}$ ). After 18 days, the two statistical groups were composed of 5 and $10 \mathrm{mg} \mathrm{L}^{-1}$ treatments, with for the highest relative AMYB mRNA level $(2.46 \pm 0.22 \mathrm{UI})$, compared with $1 \mathrm{mg} \mathrm{L}^{-1}$ and the control $(1.08 \pm 0.26 \mathrm{UI})$. For the AMYA gene, no significant differences of mRNA level were noted between the treatments after 10 and 18 days (Table 2, Figure $3 A$ ). 
The present study investigated the effect of dietary starch concentration on the amylase enzymes in the digestive gland of oysters, examining enzymatic and molecular responses to improve our understanding of digestive regulation in Crassostrea gigas.

A significant decrease of $20 \%$ was observed in the mean wet weight of oysters after 10 and 18 days of conditioning at the highest starch concentration $\left(10 \mathrm{mg} \mathrm{L}^{-1}\right)$, suggesting a negative effect on growth. Detrimental physiological responses were previously reported with high- or moderate-starch diets, which can be explained by several processes. An inhibition of amylase release could occur due to amylase inhibitors able to block the active site of the enzyme, as observed in crickets by Woodring et al., (2009). A repressive mechanism could also be at work, due to a high circulating glucose concentration, as observed in Artemia salina by Samain et al., (1980). A detrimental physiological response can also result from a decrease of the filtration rate and /or particle retention efficiency due to saturating concentration of starch particles in the environment. Changes in retention efficiencies have already been reported in C. gigas, depending on particle concentration (Barillé et al., 1993), suggesting that this species is able to change its feed intake according to food availability. All of these physiological perturbations can have negative consequences for the digestive system, in terms of ingestion, size of digestive tubules and of the digestive gland, and the synthesis of digestive enzymes, all of which have already been reported to affect oyster growth (Huvet et al., 2008). We therefore supposed a gradual or moderate detrimental physiological response with high-starch diet that would explain level of AMYB mRNA for the $5 \mathrm{mg} \mathrm{L}^{-1}$ treatment that appeared intermediate between the group composed with $1 \mathrm{mg} \mathrm{L}^{-1}$ and the control (difference of 1.8x), and the $10 \mathrm{mg} \mathrm{L}^{-1}$ treatment (difference of $1.4 \mathrm{x}$ ). The 10 $\mathrm{mg} \mathrm{L}^{-1}$ treatment might indeed lead to a negative feed-back regulatory control of amylase activity in oysters creating an unrealistic situation when very high particle concentration was used. Finally, the $1 \mathrm{mg} \mathrm{L}^{-1}$ treatment led to wet weight values slightly higher than the control (although not significantly different) and should be further tested to assess as an effective food supplement for oysters. It would be useful to test the potential of low starch supplements and algal diets containing species naturally rich in starch for improving growth of oyster spat in commercial or experimental nurseries.

For amylase activity, a dramatic decrease was observed at only $5 \mathrm{mg} \mathrm{L}^{-1}$ added starch, compared with the $1 \mathrm{mg} \mathrm{L}^{-1}$ supplement and pure C. gracilis (control) diet. This decrease of specific amylase activity is observed simultaneously with an increase of $\mathrm{Km}$ that would lead to a lower affinity for the substrate with an increasing starch concentration. When more than one enzymes can use the same substrate, as is supposed here with the two amylase enzymes $A$ and $B$, some form of regulation will typically have evolved to allow efficient use of the substrate over a range of substrate concentration. When the substrate becomes saturating, enzymatic activity is progressively limited to a maximum constant rate and cannot be controlled further without changing the enzymatic concentration or $\mathrm{Km}$. Consequently, an increase in $\mathrm{Km}$ will provide a greater control of enzymatic activity over a broader substrate concentration range. This can result in the synthesis or up-regulation of an enzymatic isoform that has a different $\mathrm{Km}$ value to the isoform synthesized under normal conditions, therefore improving adaptation to the high substrate concentration. One or just a few amino acid substitutions are sufficient to achieve adaptation via variation in kinetic properties. This was observed for LDH orthologs of confamilial and congeneric fishes in response to temperature, and is due to only a few specific amino acid substitutions (Somero, 2004). We expect the specific amylase activity assayed in the present work to result from the mixture of at least two enzymatic isoforms, corresponding to $A$ and $B$, which we presume to have different $\mathrm{Km}$ values. Observed changes in $\mathrm{Km}$ could be due to variation in the ratio of these two proteins in response to variation in starch in the diet, suggested by the relative mRNA levels assayed for amylase genes A and B. For amylase expression, a significant increase (1.9 to $2.6 \times$ in 10 and $5 \mathrm{mg} \mathrm{L}^{-1}$ starch supplement treatments, respectively) in translatable mRNA for gene B was observed whereas no significant changes were observed for gene $A$. 
Even though correlation between mRNA and protein expression may not hold true for some genes, most changes in gene expression profiles are reflected in the proteome, as shown in yeast where $87 \%$ of the protein levels were correlated with their mRNA expression levels (Newman et al., 2006). This was also the case in mammalian pancreatic acinar cells, where differences in amylase protein concentration were thought to be mostly related directly to amylase gene transcription (Logsdon et al., 1987).

Our data suggested that amylase $\mathrm{Km}$ increase could, at least partially, be linked to an increase in translatable mRNA for the amylase $B$ form in response to variation in starch availability. Amylase B enzyme is expected to have a higher $\mathrm{Km}$ than amylase $\mathrm{A}$ enzyme, and should be the subject of further enzymatic study. For further investigation of this point, amylase A and B enzymes would need to be specifically assayed. Alternatively, amylase A and $B$ functions could be assessed on the basis of altered phenotypes, especially for enzymatic properties associated with gene disruption, using methods such as that recently developed in oyster with RNA inteference (Fabioux et al., 2009). In this context, the high level of polymorphism of amylase A and B genes (Sellos et al., 2003) needs to be taken into account considering that polymorphism affects digestive properties and growth in oyster (Huvet et al., 2008) and that individuals that are homozygous for particular amylase alleles have displayed significant variation of $\mathrm{Km}$ values in Drosophila subobscura (Savic et al., 2008).

To conclude, we demonstrated the capacity for amylase gene $B$ to be regulated at the mRNA level when starch varied in the food, whereas the gene $A$ was not regulated under these conditions. This is the first study that has found evidence for a putative role of the oyster amylase gene $B$ in digestive processes and the first time that changes in its expression have been recorded. Genes A and B had been previously found to encode mature proteins of 500 and 499 amino acids, respectively, with $94 \%$ similarity (Sellos et al., 2003). None of our previous investigation showed any regulation of gene $B$ transcription and only showed weak levels of $A M Y B$ mRNA; so the functional role of the gene $B$ was in question (Huvet et al., 2003; Huvet et al., 2008). The variation we observed for amylase B mRNA level in the present study is in agreement with the adaptation of amylase gene $B$ already reported in some vertebrates (Brannon, 1990). Its role might be crucial in the adaptation of $C$. gigas to variation in starch concentration in the diet, whereas amylase gene $A$ has already been suggested to adapt digestive processes in response to variation in quantity of the same alga in the oyster diet (Huvet et al., 2003). Adaptive significance of gene-enzyme polymorphism depending on the carbohydrate composition of the diet, especially at limiting or low level, would make an interesting study, through a multifactorial experiment like that developed for Drosophila subobscura (Andjelković et al., 2003), particularly considering that activity regulation is mostly important for the adaptation to the environment with respect to the level of starch it contains (Fujimoto et al., 1999).

\section{Acknowledgements}

We are indebted to $\mathrm{H}$. McCombie for her help with the English. We thank the staff of the Argenton station for rearing the experimental oysters under controlled conditions and $\mathrm{M}$. Prudence for technical assistance. Many thanks to F. Pernet for statistical advice. This work was partly supported by the Bureau des Ressources Génétiques (contract n05/5210460/YF) and by a Région Basse-Normandie grant. 
Andjelković, M., Savić, T., Milanović, M., Stamenković-Radak, M., 2003. Adaptive significance of amylase polymorphism in Drosophila. XII. density- and frequency-dependent selection at the Amy locus in Drosophila subobscura reared on media with different carbohydrate composition. J Zool Syst Evol Res 41, 137-143.

Barillé, L., Prou, J., Héral, M., Bougrier, S., 1993. No influence of food quality, but rationdependent retention efficiencies in the Japanese oyster Crassostrea gigas. J Exp Mar Biol Ecol 171, 91-106.

Bayne, B.L., 1976. Marine Mussels, Their Ecology and Physiology. Cambridge University Press, London, pp 494.

Borowsky, R., 1984. Environmental control of amylase phenotype in amphipods of the genus Gammarus. Biol Bull 167, 647-657.

Brannon, P.M., 1990. Adaptation of the exocrine pancreas to diet. Annu Rev Nutr 10, 85-105.

Fabioux, C., Huvet, A., Lelong, C., Robert, R., Pouvreau, S., Daniel, J.Y., Minguant, C., Le Pennec, M., 2004. Oyster vasa-like gene as a marker of the germline cell development in Crassostrea gigas. Biochem Biophys Res Commun 320, 592-598.

Fabioux, C., Corporeau, C., Quillien, V., Favrel, P., Huvet, A., 2009. In vivo RNA interference in oyster: vasa silencing inhibits germ cell development. FEBS J 276, 2566-2573.

Fujimoto, J., Kanou, C., Eguchi, Y., Matsuo, Y., 1999. Adaptation to a Starch Environment and Regulation of a-Amylase in Drosophila. Biochem Genet 37, 53-62.

Guarna, M.M., Borowsky, R.L., 1995. Biochemical properties of amylase isozymes from Gammarus palustris. A comparative study. Comp Biochem Physiol B 112, 619-628.

Huvet, A., Dubois, S., Daniel, J.Y., Quéré, C., Prudence, M., Van Wormhoudt, A., Sellos, D., Samain, J.F., Moal, J., 2003. Tissue expression of two amylase genes in the Pacific oyster Crassostrea gigas. Effects of two different food rations. Aquaculture 228, 321-333.

Huvet, A., Herpin, A., Dégremont, L., Labreuche, Y., Samain, J.F., Cunningham, C., 2004. The identification of genes from the oyster Crassostrea gigas that are differentially expressed in progenies exhibiting opposed susceptibility to summer mortality. Gene 343, 211-220.

Huvet, A., Jeffroy, F., Fabioux, C., Daniel, J.Y., Quillien, V., Van Wormhoudt, A., Moal, J., Samain, J.F., Boudry, P., Pouvreau, S., 2008. Association between growth, foodconsumption related traits and amylase gene polymorphism in the Pacific oyster Crassostrea gigas. Anim Genet 39, 662-665.

Ibarrola, I., Navarro, E., Iglesias, J.I.P., 1998. Short-term adaptation of digestive processes in the cockle Cerastoderma edule exposed to different food quantity and quality. J Comp Physiol B 168, 32-40.

Ibarrola, I., Etxeberria, M., Iglesias, J.I.P., Urrutia, M.B., Angulo A., 2000. Acute and acclimated responses of the cockle Cerastoderma edule (L.) to changes in food quality and quantity. II. Enzymatic, cellular and tissular responses of the digestive gland. J Exp Mar Biol Ecol 252, 199-219.

Le Moullac, G., Klein, B., Sellos, D., Van Wormhoudt, A., 1997. Adaptation of trypsin, chymotrypsin and alpha-amylase to casein level and protein source in Penaus vannamei (Crustacea Decapoda). J Exp Mar Biol Ecol 208, 107-125.

Logsdon, C.D., Perot, K.J., McDonald, A.R., 1987. Mechanism of glucocorticoid-induced increase in pancreatic amylase gene transcription. J Biol Chem 262, 15765-15769.

Lowry, O.H., Rosebrough, N.J., Farr, A.L., Randall, R.J., 1951. Protein measurement with the Folin phenol reagent. J Biol Chem 193, 251.

Moal, J., Martin-Jezequel, V., Harris, R.P., Samain, J.F., Poulet, S.A., 1987. Interspecific and intraspecific variability of the chemical composition of marine phytoplancton. Oceanol Acta 10, 339-346.

Moal, J., Daniel, J.Y., Sellos, D., Van Wormhoudt, A., Samain, J.F., 2000. Amylase mRNA expression in Crassostrea gigas during feeding cycles. J Comp Physiol B 170, 21-26. 
Newman, J.R., Ghaemmaghami, S., Ihmels, J., Breslow, D.K., Noble, M., DeRisi, J.L., Weissman, J.S., 2006. Single-cell proteomic analysis of $S$. cerevisiae reveals the architecture of biological noise. Nature 441, 840-846.

Nikapitiya, C., Oh, C., Whang, I., Kimb, C.G., Leeb, Y.H., Kimb, S.J., Lee, J., 2009. Molecular characterization, gene expression analysis and biochemical properties of alphaamylase from the disk abalone, Haliotis discus discus. Comp Biochem Physiol B 152, 271281.

Pernet, F., Tremblay, R., Comeau, L., Guderley, H., 2007. Temperature adaptation in two bivalve species from different thermal habitats: energetics and remodelling of membrane lipids. J Exp Biol 210, 2999-3014.

Pfaffl, M.W., 2001. A new mathematical model for relative quantification in real-time RT-PCR. Nucleic Acids Res. 29, 45.

Powell, J.R., Andjelkovic, M., 1983. Population genetics of Drosophila amylase: IV. Selection in laboratory populations maintained on different carbohydrates. Genetics 103, 675-689.

Prudence, M., Moal, J., Boudry, P., Daniel, J.Y., Quéré, C., Jeffroy, F., Mingant, C., Ropert, M., Bédier, E., Van Wormhoudt, A., Samain, J.F., Huvet, A., 2006. An amylase gene polymorphism is associated with growth differences in the Pacific cupped oyster Crassostrea gigas. Anim Genet 37, 348-351.

Samain, J.F., Daniel, J.Y., Le Coz, J.R., 1977. Trypsine, amylase et protéines du zooplancton, dosage automatique et manuel. J Exp Mar Biol Ecol 29, 279-289.

Samain, J.F., Moal, J., Daniel, J.Y., Le Coz, J.R., Jezequel, M., 1980. The digestive enzymes amylase and trypsin during the development of Artemia: effect of food conditions. In, The Brine Shrimp Artemia, Vol. 2, edited by G. Persoone, P. Sorgeloos, O. Roels and E. Jaspers, Universa Press, Wetteren, Belgium, pp239-255.

Samain, J.F., Salaun, M., Diouris, M., Daniel, J.Y., Le Coz, J.R., Moal, J., 1991. Digestive enzymes during development of Pecten maximus, relations with ingestion and absorption processes. 13th. International Congress of E.S.C.P.B.: Research for aquaculture, fundamentals and applied aspects. Antibes-Juan Les Pins. 6-10 Octobre 1991.

Savic, T., Milanovic, M., Stamenkovic-Radak, M., Andjelkovic, M., 2008. Adaptive significance of amylase polymorphism in Drosophila: Effect of substrates with different carbohydrate composition on some life-history traits of Drosophila subobscura. Russ J Genet 44, 279-285.

Sellos, D., Moal, J., Dégremont, L., Huvet, A., Daniel, J.Y., Nicoulaud, S., Boudry, P., Samain, J.F., Van Wormhoudt, A., 2003. Structure of amylase genes in populations of Pacific cupped oyster (Crassostrea gigas): tissue expression and allelic polymorphism. Mar Biotechnol 5, 360-372.

Somero, G.N, 2004. Adaptation of enzymes to temperature: searching for basic "strategies". Comp Biochem Physiol B 139, 321-333.

Wicker, C., Puigserver, A., Scheele, G., 1984. Dietary regulation of levels of actine mRNA coding for amylase and serine protease zymogens in the rat pancreas. Eur J Biochem 139, 381-387.

Woodring, J., Diersch, S., Lwalaba, D., Hoffmann, K.H., Meyering-Vos, M., 2009. Control of the release of digestive enzymes in the caeca of the cricket Gryllus bimaculatus. Physiol Entomol 34, 144-151. 


\section{Table 1}

Wet flesh weight (in grams) of oysters after 10 (T1) and 18 (T2) days of food conditioning in four different treatments. Oysters were fed a Chaetoceros gracilis diet at a daily ration equal to $8 \%$ dry weight algae/dry weight oyster for the control (c). For the treatments, a starch supplement was added at $1 \mathrm{mg} \mathrm{L}^{-1}, 5 \mathrm{mg} \mathrm{L}^{-1}$ or $10 \mathrm{mg} \mathrm{L}^{-1}$.

\begin{tabular}{ccccc}
\hline & $\mathrm{C}$ & $1 \mathrm{mg} \mathrm{L}^{-1}$ & $5 \mathrm{mg} \mathrm{L}^{-1}$ & $10 \mathrm{mg} \mathrm{L}^{-1}$ \\
\hline $\mathrm{T} 1$ & $12.89 \pm 3.81$ & $14.09 \pm 4.94$ & $13.18 \pm 5.90$ & $10.52 \pm 4.96$ \\
& $\mathrm{AB}$ & $\mathrm{A}$ & $\mathrm{A}$ & $\mathrm{B}$ \\
$\mathrm{T} 2$ & $12.83 \pm 4.35$ & $13.71 \pm 3.88$ & $13.69 \pm 4.17$ & $10.53 \pm 2.88$ \\
& $\mathrm{~A}$ & $\mathrm{~A}$ & $\mathrm{~A}$ & $\mathrm{~B}$ \\
\hline
\end{tabular}

\section{Table 2}

Summary of the split-split plot three-way ANOVAs on the effect of diet (starch supplementation) and sampling date on wet flesh weight, specific amylase activity, apparent Michaelis-Menten constant $\left(K_{\mathrm{M}}\right)$ and relative levels of amylase transcripts (AMYA and $A M Y B)$.

\begin{tabular}{lccccccccccc}
\hline & \multicolumn{2}{c}{ Weight } & \multicolumn{2}{c}{ Activity } & \multicolumn{3}{c}{$K_{\mathrm{M}}$} & \multicolumn{3}{c}{ AMYA } & \\
$\begin{array}{l}\text { Sources of } \\
\text { variation }\end{array}$ & $F$ & $P$ & $F$ & $P$ & $F$ & $P$ & $F$ & $P$ & $F$ & $P$ \\
\hline Diet & 14.7 & $\mathbf{0 . 0 3 6}$ & 79.57 & $\mathbf{0 . 0 0 3 4}$ & 13.22 & $\mathbf{0 . 0 4 5}$ & 0.52 & 0.699 & 7.15 & $\mathbf{0 . 0 0 2 6}$ \\
Tank & 2.94 & 0.128 & 1.72 & 0.265 & 0.01 & 0.931 & 0.34 & 0.596 & 2.40 & 0.139 \\
Diet x Tank & 0.48 & 0.822 & 2.77 & 0.078 & 1.25 & 0.326 & 2.30 & 0.113 & 1.56 & 0.235 \\
Date & 0.66 & 0.418 & 0.24 & 0.634 & 0.43 & 0.52 & 0.15 & 0.704 & 1.75 & 0.203
\end{tabular}

Significant probabilities are in bold. Data of wet flesh weight, relative levels of amylase transcripts and apparent Michaelis-Menten constant were log-transformed. Specific amylase activity data were square root transformed. 
Figure 1.

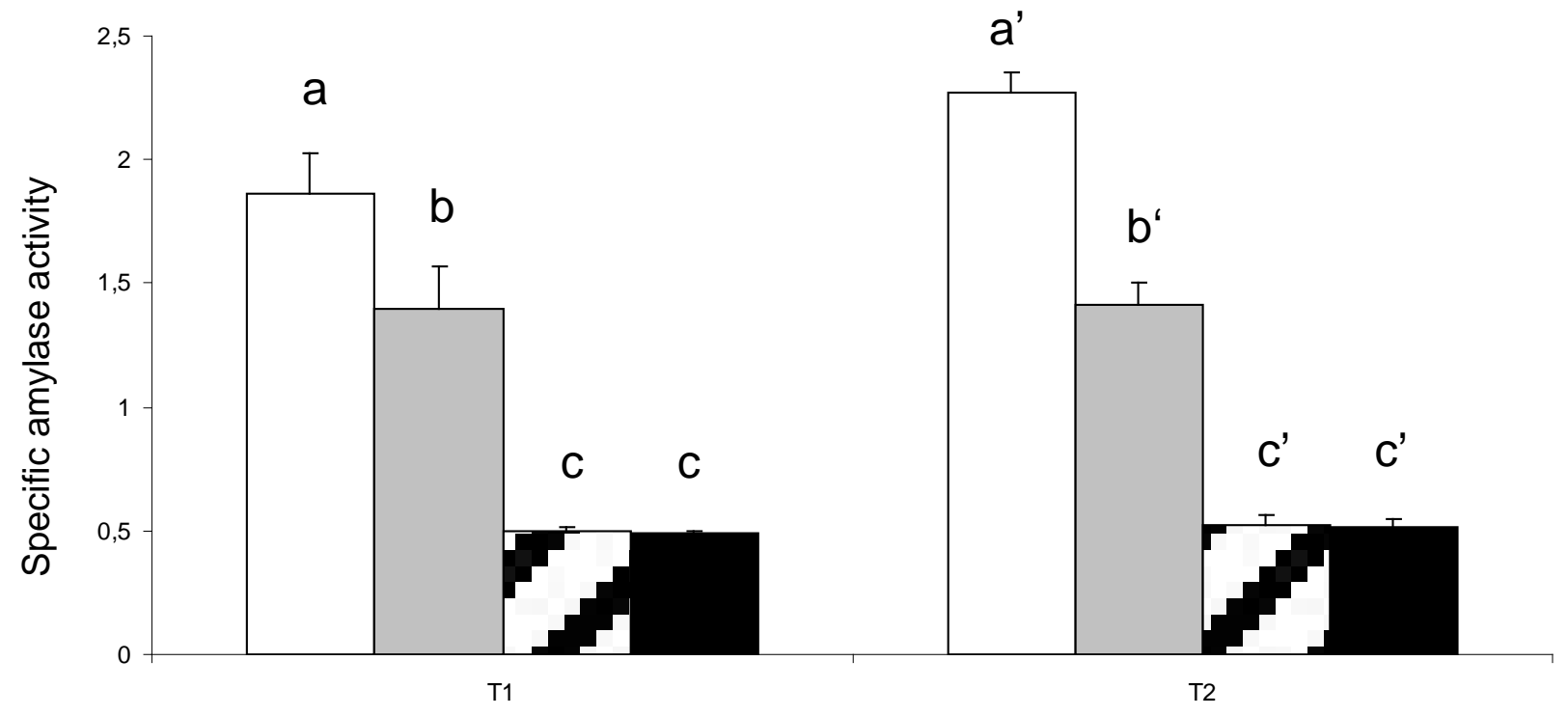

Figure 1. Specific amylase activity (given in UI/mg soluble protein) in the digestive gland of oysters after 10 (T1) and 18 (T2) days of food conditioning in four different replicated treatments. Oysters were fed a Chaetoceros gracilis diet at a daily ration equal to $8 \%$ dry weight algae/dry weight oyster for the control (white bars). For the treatments, a starch supplement was added at $1 \mathrm{mg} \mathrm{L}^{-1}$ (grey bars), $5 \mathrm{mg} \mathrm{L}^{-1}$ (hatched bars) or $10 \mathrm{mg} \mathrm{L}^{-1}$ (black bars). As no significant effect of the factor "raceway" nor interaction between diet and raceway were observed, the replicate data were pooled in the histograms. Results are therefore expressed as means of 4 pools of 8 digestive glands \pm standard deviation. Multiple comparisons were made between treatments using Tukey's HSD method at the $5 \%$ level: homogenous groups have the same letters. 


\section{Figure 2.}

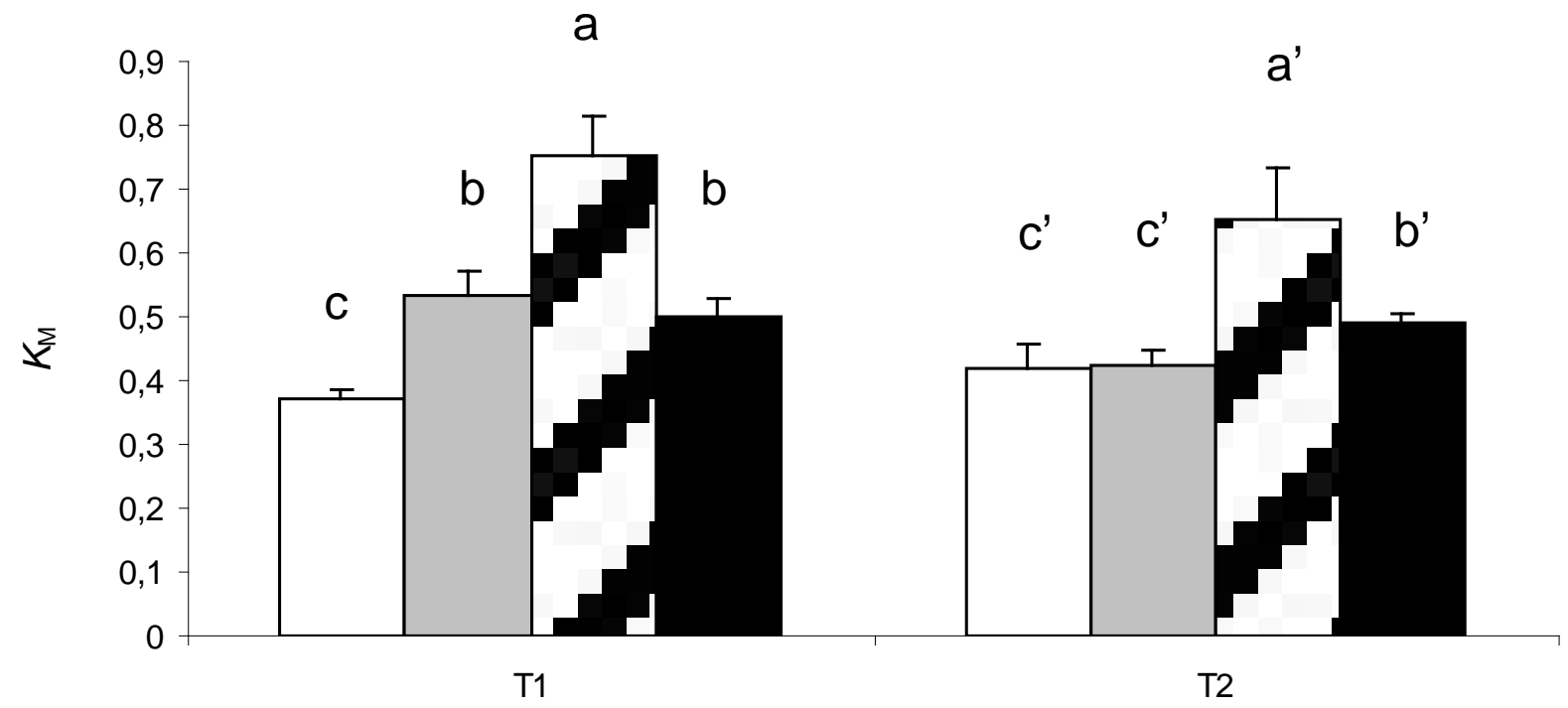

Figure 2. Apparent Michaelis-Menten constant ( $K_{\mathrm{M}}$ in $\mathrm{mg} / \mathrm{ml}$ of starch) in the digestive gland of oysters after 10 (T1) and 18 (T2) days of food conditioning in four different replicated treatments. Oysters were fed a Chaetoceros gracilis diet at a daily ration equal to $8 \%$ dry weight algae/dry weight oyster for the control (white bars). For the treatments, a starch supplement was added at $1 \mathrm{mg} \mathrm{L}^{-1}$ (grey bars), $5 \mathrm{mg} \mathrm{L}^{-1}$ (hatched bars) and $10 \mathrm{mg} \mathrm{L}^{-1}$ (black bars). As no significant effect of the factor "raceway" nor interaction between diet and raceway were observed, the replicate data were pooled in the histograms. Results are therefore expressed as means of 4 pools of 8 digestive glands \pm standard deviation. Multiple comparisons were made between treatments using Tukey's HSD method at the $5 \%$ level; homogenous groups have the same letters. 


\section{Figure 3.}
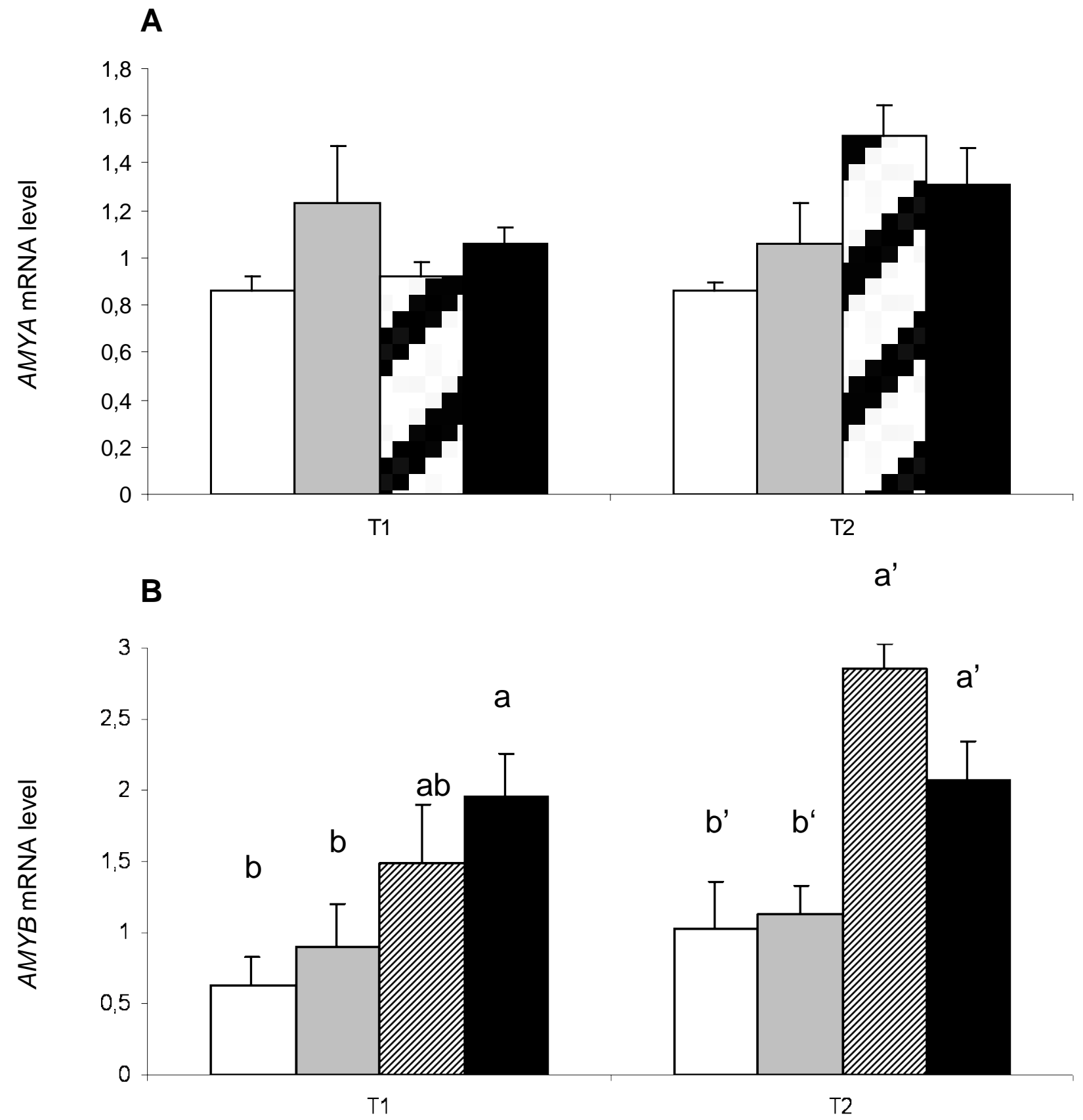

Figure 3. Levels of amylase transcripts ( $\mathrm{A}: A M Y A$ and $\mathrm{B}: A M Y B)$ relative to elongation factor transcripts in the digestive gland of oysters after 10 (T1) and 18 (T2) days of food conditioning in four different replicated treatments (mean \pm standard deviation). Oysters were fed a Chaetoceros gracilis diet at a daily ration equal to $8 \%$ dry weight algae/dry weight oyster for the control (white bars). For the treatments, a starch supplement was added at 1 $\mathrm{mg} \mathrm{L}^{-1}$ (grey bars), $5 \mathrm{mg} \mathrm{L}^{-1}$ (hatched bars) and $10 \mathrm{mg} \mathrm{L}^{-1}$ (black bars). As no significant effect of the factor "raceway" nor interaction between diet and raceway were observed, the replicate data were pooled in the histograms. Results are therefore expressed as means of 4 pools of 8 digestive glands \pm standard deviation. Multiple comparisons were made between treatments using Tukey's HSD method at the $5 \%$ level; homogenous groups have the same letters. 